\title{
Evidence of species sorting driving aquatic beetles associated with woody debris in a transitional region between Cerrado and Atlantic Forest biomes
}

\author{
Francisco Valente-Neto • Victor S. Saito • Tadeu Siqueira • \\ Alaide Aparecida Fonseca-Gessner
}

Received: 19 June 2015/Accepted: 6 February 2016/Published online: 18 February 2016

(C) Springer Science+Business Media Dordrecht 2016

\begin{abstract}
We investigated (1) the variation of both species composition and species relative abundances of aquatic beetles associated with submerged woody debris in a transitional region between Cerrado (Brazilian savannah) and Atlantic Forest biomes; and (2) which assembling processes are more associated with the observed patterns, species sorting or mass effects. We hypothesized that the marked differences between Cerrado and Atlantic Forest streams regarding vegetation composition and structure would produce different environmental conditions for stream beetle faunas assembling. We used spatial explicit multivariate techniques to analyze whether metacommunity patterns were more associated with
\end{abstract}

Handling Editor: Piet Spaak.

Electronic supplementary material The online version of this article (doi:10.1007/s10452-016-9569-0) contains supplementary material, which is available to authorized users.

F. Valente-Neto · V. S. Saito

Programa de Pós-Graduação em Ecologia e Recursos

Naturais, Universidade Federal de São Carlos, Rod.

Washington Luiz km 235, São Carlos,

São Paulo CEP 13565-905, Brazil

F. Valente-Neto $(\bowtie)$

Programa de Pós-Graduação em Ecologia e Conservação,

Universidade Federal de Mato Grosso do Sul,

Campo Grande, Mato Grosso do Sul CEP 79070-900,

Brazil

e-mail: fvalenteneto@gmail.com environmental variables, indicating a major role of species sorting, or with spatial variables, indicating intense dispersal. We found distinct communities within each biome in terms of both changes in taxonomic composition and species relative abundance driven by environmental factors. Biome type, a regional scale variable, and variation in dissolved oxygen levels, a local scale variable, were the best explanatory variables of variation in metacommunity structure. We did not find any evidence of the influence of processes related to the spatial configuration of streams. Altogether our results pointed to species sorting structuring saproxylic beetles assemblages patterns.

Keywords Ecotone $\cdot$ Metacommunity $\cdot$ Saproxylic · Tropical streams

\author{
T. Siqueira \\ Departamento de Ecologia, Instituto de Biociências, \\ UNESP - Universidade Estadual Paulista, Campus Rio \\ Claro, Av. 24-A 1515, Rio Claro, \\ São Paulo CEP 13506-900, Brazil \\ A. A. Fonseca-Gessner \\ Departamento de Hidrobiologia, Universidade Federal de \\ São Carlos, Rod. Washington Luiz km 235, São Carlos, \\ SP CEP 13565-905, Brazil
}




\section{Introduction}

Communities within a biome are more similar when compared to communities among biomes (Lomolino et al. 2010) and aquatic communities do not seem to be an exception of this pattern (Corkum 1992; Mykrä et al. 2004). Studies in aquatic systems show that community dissimilarity among biomes could be attributed to the process of environmental filtering and to the biogeographic history of biomes (Corkum 1992; Feminella 2000). Communities can also vary according to geographic distance-closer communities are more similar than distant ones because of differential dispersal forces among them (Nekola and White 1999). Transitional regions between biomes are defined by a change in the dominant life forms or generalist taxa due to climatic variation and other environmental variables (e.g., soil) across a region (Gosz and Sharpe 1989). Species diversity and community variation is predicted to be greater in transitional regions than in core biome areas, because these areas allow species dispersal between biomes and cooccurrence (McKnight et al. 2007; van Rensburg et al. 2009). Thus, transitional areas are key to understand the ecological processes driving community variation (van Rensburg et al. 2009).

Metacommunity ecology provides a general framework to understand the relative role of local control (biotic and abiotic factors) and dispersal-related process in structuring communities (Leibold et al. 2004; Logue et al. 2011). Metacommunity ecology were originally outlined in four perspectives (species sorting, patch dynamics, mass effects and neutral), varying in the relative role given to dispersal, species characteristics and local forces (both abiotic and biotic processes) (Leibold et al. 2004). In transition regions between biomes, different metacommunity processes may drive species composition in aquatic systems. For example, biomes have specific environmental conditions (e.g. climatic, soil) and, consequently, plant species, which provide different environmental conditions for animal species. In this sense, communities would vary between biomes due to these differences, following a species sorting model. However, due to proximity in transitional regions, intense dispersal from neighboring sites between biomes could mask the effects of species sorting and strengthen the effects of spatial configuration. For example, intense dispersal from a source population of one biome could maintain sink populations in the neighboring biome, even if this biome requires different species fitness and traits (mass effects, Mouquet and Loreau 2003; Leibold et al. 2004).

Streams are part of dendritic networks surrounded by a terrestrial matrix that includes the biome vegetation. Aquatic beetles rely on terrestrial organic matter inputs for feeding and habitat, especially those associated with submerged woody debris (ValenteNeto and Fonseca-Gessner 2011; Valente-Neto et al. 2015). For example, wood gougers and borers, the most abundant beetles associated with submerged woody debris, play an important role converting coarse (woody debris) into fine organic matter (fecal pellets) (Steedman and Anderson 1985; Mckie and Cranston 1998). In the Neotropical region, Lutrochus germari and Stegoelmis sp produce a large amount of fecal pellets (Valente-Neto and Fonseca-Gessner 2011; Valente-Neto et al. 2015). Environmental factors appear to be the dominant drivers of composition of aquatic insects associated with wood debris, despite very few studies have examined the role of processes related to spatial dynamics. Some authors claim that insect species inhabiting woody debris are generalists showing a relationship with factors such as wood breakdown stage and stream characteristics (Spänhoff et al. 2000; Kaller and Kelso 2007). Others argue the importance of woody type and surrounding vegetation, providing evidences for insect communities composed of opportunistic or specialist species (McKie and Cranston 1998; Hoffmann and Hering 2000; McKie and Cranston 2001; Valente-Neto et al. 2015). Following these strict relationship of these beetles with the surrounding vegetation (Mckie and Cranston 1998; Hoffmann and Hering 2000; McKie and Cranston 2001), biome type would be important driver of aquatic beetles associated with submerged woody debris, since different biomes have a specific plant community, including the riparian zone. Thus, aquatic beetles associated with woody debris (saproxylic beetles) are interesting models for understanding processes responsible for their distribution in transition regions between biomes.

In Brazil, the contact region between Cerrado (Brazilian savannah) and Atlantic Forest in São Paulo state provides an opportunity to understand the influence of different drivers shaping biodiversity 
distribution in transition regions. Cerrado and Atlantic Forest are characterized by distinct plant composition, including the riparian vegetation (Oliveira-Filho and Ratter 2002; Online resource 1). This difference in composition between the two biomes creates different niche opportunities for aquatic beetles that are dependent on woody debris, including woody traits-e.g., Cerrado wood species have higher density compared to those of Atlantic Forest (Marcati et al. 2001; Chave et al. 2006). Accordingly, the distinct riparian vegetation found in Cerrado and Atlantic Forest and their proximity in some regions lead to an intriguing question: what is the relative role of different factors structuring the composition of aquatic beetles associated with wood debris in transitional zones?

With this in mind, we aim to answer the following questions: (1) Do Cerrado and Atlantic Forest streams have distinct aquatic beetles associated with woody debris, in terms of species composition and species relative abundances, in a transitional region between these two biomes? (2) Which metacommunity processes are driving these patterns? For instance, riffle beetles, the most abundant organisms of beetle communities associated with submerged woody debris (Valente-Neto et al. 2015), do not seem to disperse intensively enough to maintain source-sink dynamics (see reviews Brown 1987; Ellicott 2008). We hypothesized that the marked differences between Cerrado and Atlantic Forest streams regarding vegetation composition and structure of (Chave et al. 2006; Oliveira-Filho and Ratter 2002) would create different environmental conditions for stream beetle faunas and would drive community assembling, in accordance with species sorting metacommunity perspective.

\section{Methods}

Study area

We conducted the study in the central and eastern region of São Paulo State (Brazil), during the dry season (June-September) of 2010. The central region of São Paulo is characterized by a transition between Cerrado (Brazilian savannah) and Atlantic Forest fragments (Durigan 2006), whereas the eastern region is characterized by two mountain chains, Serra da Mantiqueira and Serra do Mar, both covered only by Atlantic Forest vegetation. The transition region is highly fragmented, mainly due to agriculture and cattle ranching. This area has both Cerrado and Atlantic Forest fragments (Fig. 1). We selected 18 low order perennial streams (first to third order), all located inside conservation units or legal forest reserves, with minimal anthropogenic impacts. Also, all streams had sand as the main bottom sediment. Among the 18 streams, 8 were located in Cerrado fragments and 10 in Atlantic Forest fragments (Fig. 1). In the central region we selected 8 Cerrado and 2 Atlantic Forest streams, while another 8 Atlantic Forest streams were selected from the eastern region. We had difficulties finding low impacts streams on the Cerrado, so we included 8 streams.

In general, the Cerrado biome is characterized by hot and seasonal weather with rainy summer and dry winter and an acidic sandy latosol soil type. Cerrado biome has a mosaic-like aspect, composed by savannas (the dominant vegetation), patches of dry forests and forests (Oliveira and Marquis 2002). Thus, this variation is recognized by five main structures types (cerradão, cerrado strict sensu, campo cerrado, campo sujo and campo limpo). The typical vegetation is a fairly dense woody savanna of shrubs and small trees. Tree species common in Cerrado included Annona crassiflora, Astronium fraxinifolium, Byrsonima coccolobifolia, B. verbascifolia, Hancornia speciosa, Kielmeyera coriacea, Qualea grandifolia, and Q. parviflora, among others (Ratter and Dargie 1992). The vegetation is adapted to drought and fire stress. Riparian vegetation has, in general, open and narrow riparian vegetation structure, interspersed between savanna vegetation. Cerrado has an area around 1,082,640 ha in São Paulo State (Kronka et al. 2005). The Atlantic Forest biome is characterized by high temperatures and rainfall, fertile soil, large variations in altitude and dense forests, where riparian vegetation is immersed (Morellato and Haddad 2000). The most common species included Euterpe edulis, Psychotria nuda, Eugenia cuprea, Guapira opposite and Rudgea jasminoides (Scudeller et al. 2001). Dense vegetation is the typical structure of Atlantic Forest biome and, differently from Cerrado biome, no borders could be recognized between Atlantic Forest typical structure and riparian forests, constituting a continuum vegetation structure. In São Paulo State Atlantic Forest occupies an area of 2,375,211 ha (Fundação SOS Mata Atlântica 2013). Both biomes are fragmented in 

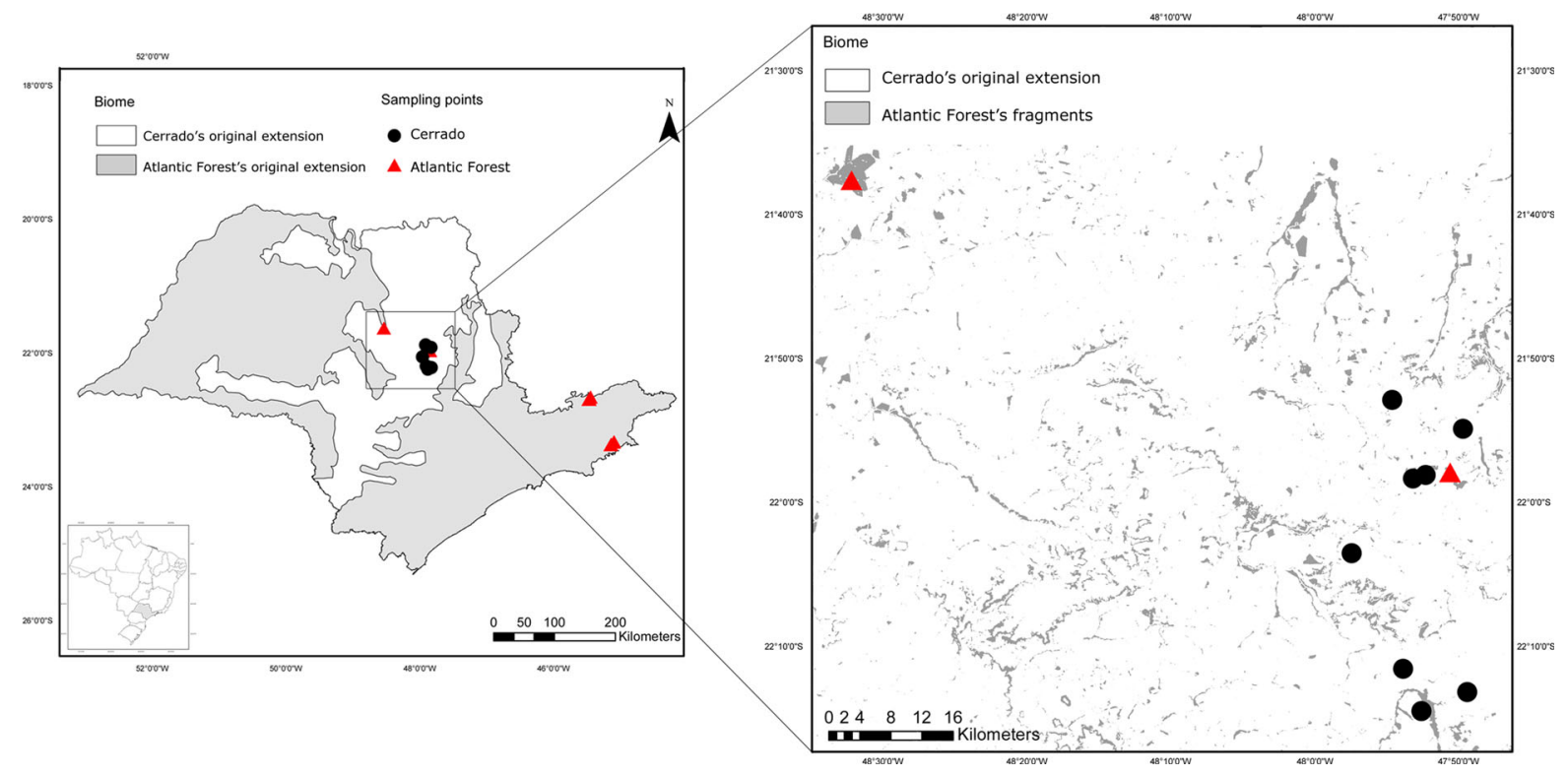

Fig. 1 Left map of São Paulo State, Brazil, showing the stream sampling sites (some are superimposed) and the original extension of both Cerrado and Atlantic Forest biomes. Right central area of São Paulo State showing part of the transitional

São Paulo State, particularly due to disorganized urban growth and agribusiness activities (Morellato and Haddad 2000).

We used literature knowledge to provide evidence that common plant species are different in Atlantic Forest and Cerrado riparian vegetation (respectively, Sanchez et al. 1999; Soares et al. 2003) (Online resource 1). We only included woody species with at least $30 \mathrm{~cm}$ of diameter at breast height (following Lorenzi 2002), i.e., capable to input woody debris in streams.

\section{Biological and environmental data}

We carried out fieldwork in the dry season of 2010 (June-September) using a $100 \mathrm{~m}$ reach in each stream to sampling and measure aquatic variables. All aquatic variables (temperature, conductivity, dissolved oxygen and $\mathrm{pH}$ ) were measured in this segment with a Yellow Spring 556 (YSI Incorporated, Yellow Springs, USA) multiparameter probe in backwater areas to avoid variation in different habitat types. Current velocity was measured in five locations (each $20 \mathrm{~m}$ ) at $10 \mathrm{~cm}$ form the stream bottom using a Global Water FP101 Flow Probe. We also recorded the region between Cerrado and Atlantic Forest. Note that the map shows Atlantic Forest fragments and the original extension of Cerrado biome, not including land use by human activities

geographic coordinates and altitude of each stream using GPS (Online resource 2).

We visited the streams once and considered each stream as a sample and the woody debris volume per stream as a sampling unit. We selected submerged woody pieces based on the following criteria (Cranston and McKie 2006; Valente-Neto et al. 2015; Roque et al. 2015): (1) presence of hollows that indicate the activity of boring organisms (both terrestrial and aquatic), (2) indications of biofilm demonstrating permanent submersion (visual detection of algae and fungi), (3) approximate size of $5-8 \mathrm{~cm}$ in diameter and maximum length of $30 \mathrm{~cm}$, to facilitate sample processing (4) absence of bark cover. Considering these criteria, we standardized the sample to a volume of $10,800 \mathrm{~cm}^{3}$ in backwater areas, with a high accumulation of woody debris. This volume was measured with a standardized box. The volume we used per stream was sufficient to include about 30-45 pieces, depending on their dimensions, ensuring, at the same time, variability of the woody debris collected (see Valente-Neto et al. 2015).

For insect surveys, wood pieces were lifted carefully from the stream bottom and placed inside a plastic bag to avoid losing insects. We transported wood pieces to the laboratory in plastic bags filled with 
water. In the laboratory, following Valente-Neto et al. (2015), we placed wood in a 0.2-mm-mesh sieve and washed it several times with a forced water jet to remove organisms. Then, we placed them in plastic containers filled with water under a lighting system. Beetles found on the wood surface were collected first. We broken up wood pieces to obtain and sort boring and internal organisms. We preserved each specimen in $70 \%$ ethanol for further identification. The specimens were identified to the lowest practical taxonomic level, with the help of taxonomic keys (Domínguez and Fernández 2009; Segura et al. 2011).

\section{Data analysis}

We ran Permutation Multivariate Analysis of Variance (PERMANOVA; Anderson 2001) to compare the beetle community composition (response matrix) in Cerrado versus Atlantic Forest regions (explanatory variable), and to test whether communities were structured based on changes in species identity or changes in abundances. To provide a continuum in community structure measures, from those emphasizing changes in species composition to those emphasizing changes in relative abundance, we ran PERMANOVA using three dissimilarity measures as suggested by Anderson et al. (2006): a Jaccard index, a Bray-Curtis index, and a Manhattan index. The Manhattan distance gives more emphasis to changes in the relative abundance of species than Bray-Curtis, as it was developed for quantitative descriptors. In this case, we transformed the compositional matrices using Hellinger transformation (Legendre and Gallagher 2001) prior to analyses. We calculated a $p$ value from 1000 permutations of least-squares residuals (Anderson et al. 2006). Complementary to that approach, we used a principal coordinate analysis to ordinate community composition using the different indexes.

To identify species that were specific to each biome, we used species indicator analysis (Dufrêne and Legendre 1997). In this analysis, indicator species are those with high abundance in one biome and low abundance in the other (specificity), and those present in most streams of this biome (fidelity) (Dufrêne and Legendre 1997). A random reallocation of sites among biomes was used to test the significance of indicator values.

To test our main hypothesis about the role of environmental and spatial-related processes structuring aquatic beetles metacommunity, we construct two explanatory matrices (environmental and spatial). The environmental predictor matrix included the biome (Cerrado and Atlantic Forest) as a categorical (dummy) variable (Legendre and Legendre 2012), mean current velocity, altitude, water temperature, dissolved oxygen, $\mathrm{pH}$, and conductivity (Online resource 2). We standardized (centered and divided by their standard deviation) environmental predictors. A Pearson correlation analysis was carried out to test the degree of association between independent environmental variables (the cutoff level for statistical significance was set at $p<0.05$ and $\left.r_{\mathrm{s}}>0.8\right)$. No variables were correlated, and all explanatory variables were included in the analysis.

The spatial variables were generated through distance-based Moran's eigenvector maps (db-MEM; Borcard and Legendre 2002). To run db-MEM, we first calculated a distance matrix - based on Euclidean distances between streams and then submitted this matrix to a principal coordinate analysis (PCoA). From this analysis, we included PCoA axes (eigenvectors) with significant patterns of spatial autocorrelation, i.e., with positive and significant $(p<0.05)$ Moran's I (see Sokal and Oden 1978). These eigenvectors represent distinct spatial patterns that are both mutually orthogonal and linearly uncorrelated (Griffith and Peres-Neto 2006). The selected spatial eigenvectors were used as (spatial) explanatory variables in our analyses (see Borcard and Legendre 2002). Spatial eigenvectors associated with high eigenvalues (e.g., the first eigenvectors) represent broad-scale patterns of relationships among sampling sites, whereas those associated with low eigenvalues represent fine-scale patterns (Griffith and Peres-Neto 2006). Spatial eigenvectors can be interpreted to represent spatial structures generated by environmental autocorrelation and biotic processes, for instance, colonization and dispersal (Dray et al. 2006).

We tested the relative importance of environmental (E) and spatial (S) variables in explaining the variation in the composition of aquatic beetles associated with woody debris by using a variation partitioning procedure (Borcard et al. 1992) applied to redundancy analysis (RDA) models (Fig. 2). Our spatial matrix is composed by eigenvectors with positive and significant $(p<0.05)$ Moran's I (see above). Environmental variables were selected by fitting environmental RDA models with forward selection procedure (Blanchet 


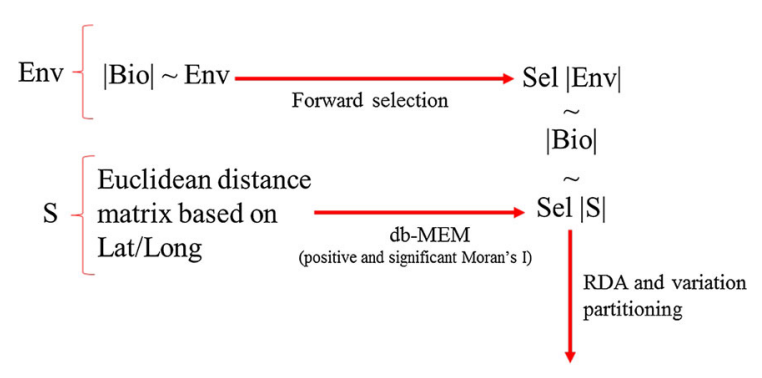

Pure effect of Env

Pure effect of S

Fig. 2 Flow chart of statistical analyses employed to assess the role of environmental and spatial components in explaining community variation. First, we selected environmental (Env) and spatial (S) variables (upper). Environmental variables were standardized and then selected by forward selection applied to redundancy analysis (RDA). Spatial variables (S) were generated by distance-based Moran's eigenvector maps and selected using positive and significant $(p<0.05)$ Moran's $I$. These selected variables (Sel) were included in variation partitioning applied to RDA analysis (bottom) as explanatory matrices (environmental and spatial) to explain community matrix (Bio). Variation partitioning was used to disentangle the effects of environment and spatial variables on community variation

et al. 2008). In this method, selection of variables is stopped if a candidate variable had a non-significant $p$ value $(p<0.05)$ or if the adjusted $R^{2}$ of the reduced model was over the value of the adjusted $R^{2}$ of the global model (see details in Blanchet et al. 2008). Then, we used the selected variables into variation partitioning, which measure the percent variation in the species data that could be attributed exclusively to environmental or spatial variables. The different components of the explanation generated by variation partitioning were as follows: total explained variation, environmental variation, spatial variation, environmental variation without the spatial component (a), spatial variation without the environmental component (c), the common fraction of variation shared by $E$ and $S$ (b), and the residual fraction of variation not explained by $E$ and $S$ (d) (Peres-Neto et al. 2006).

All analyses were performed in $\mathrm{R}$ software using vegan (Oksanen et al. 2014) and pack for packages (Dray et al. 2011).

\section{Results}

We collected and identified 1617 specimens belonging to 29 genera (Online resource 3). Elmidae was the most abundant family (48\%) and had 15 genera, of which
Elmidae spB was the most abundant taxa of this family, followed by Heterelmis. Lutrochidae is a monogeneric family that was represented by L. germari with $42 \%$ of the total abundance, i.e., the most abundant genus in this study. Other families were found in low numbers, for example Dryopidae constituted $3 \%$ of total abundance and Ptilodactylidae, Hydraenidae, Staphylinidae, Scirtidae, Hydrophilidae, Gyrinidae and Dytiscidae with less than $1 \%$ of the total abundance.

In general, community composition differed between Cerrado and Atlantic Forest streams using all dissimilarity measures (PERMANOVA, Table 1; PCoA, Fig. 3). Three taxa were considered indicators of specific biomes. L. germari, and Staphylinidae sp.1 were strictly related to Atlantic Forest and Stegoelmis was an indicator for Cerrado streams (see Table 2 for indicator values and significance values). The other taxa did not have strong fidelity (presence in most streams of a biome) and specificity (high abundance in one biome and low abundance in the other) to Cerrado or Atlantic Forest biomes.

Distance-based Moran's eigenvector maps generated six eigenvectors; however, just one was positive and significant (spatial eigenvector 1 ; Moran $=0.95$; $p=0.01$ ), which was used as our spatial component. Biome type, dissolved oxygen, altitude and temperature were the main environmental variables responsible for grouping Cerrado and Atlantic Forest community composition (Fig. 4). Biome type (Adj $R^{2}=0.20, p<0.01$ ) and dissolved oxygen (Adj $\left.R^{2}=0.24, \quad p=0.04\right)$ were retained by forward selection in the environmental component (Table 3) and used in variation partitioning. Environmental component, rather than spatial, better explained the variation in community composition of beetles associated with woody debris. Variance partitioning showed that in total, we could explain $22 \%$ $(p=0.01)$ of the variation in community structure by environmental and spatial variables. Pure

Table 1 Results of PERMANOVA analysis between Cerrado and Atlantic Forest streams using the following distance measures: Jaccard index, Bray-Curtis index, and Manhattan index

\begin{tabular}{llc}
\hline Measure & $F$-statistic & $p$ value \\
\hline Jaccard & 3.02 & 0.002 \\
Bray-Curtis & 4.06 & 0.001 \\
Manhattan & 6.22 & 0.001 \\
\hline
\end{tabular}



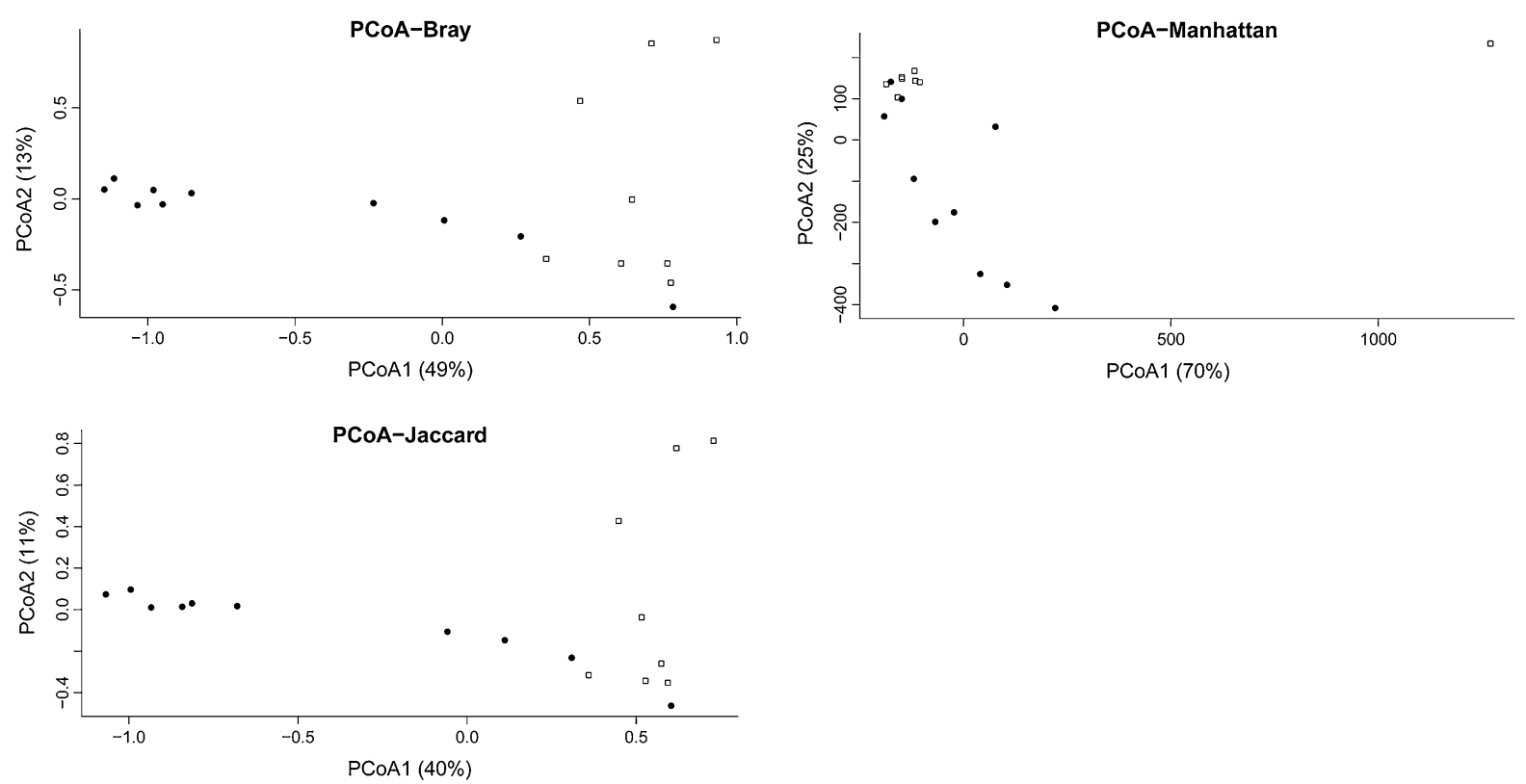

Fig. 3 Ordination produced by principal coordinate analysis of aquatic beetles community in Atlantic Forest (filled circles) and Cerrado (Brazilian savannah) (open squares) streams using different index (Bray Curtis, Manhattan and Jaccard)

environmental component explained $15 \%(p=0.05)$ of variation, while pure spatial variables did not contribute to explain metacommunity variation (Table 4).

\section{Discussion}

Environmental factors were the main driver structuring communities of saproxylic beetles in streams, even in a region of contact between biomes, where dispersal should not be limited. Biome type, a regional scale variable, and dissolved oxygen, a local scale variable were the main variables explaining the difference between Cerrado and Atlantic Forest communities. This supports the hypothesis that communities are structured by environmental filters operating at successive scales (Poff 1997). Our results are in accordance with the general role of species sorting structuring metacommunities (Logue et al. 2011; Soininen 2014). However, they disagree partially with a recent study showing the influence of dispersal limitation shaping elmid metacommunity structure (almost half of our beetles abundance) (McCreadie and Bedwell 2014), and with studies from the same region that showed influence of spatial variables in the distributions of stoneflies (Roque et al. 2008) and chironomids (Roque et al. 2010). Two characteristics may have influenced the lack of a spatial signature in our study. First, some groups found in both biome types, such as the elmids Heterelmis, Hexacylloepus and Neolmis, are associated with multiple organic substrates (generalists) and did not show specificity for any biome as shown by the species indicator analysis. In this sense, these taxa could inhabit any stream in our study area extension and thus would not show any spatial signature. Second, the specialist beetle borers and gougers of submerged woody debris (ValenteNeto and Fonseca-Gessner 2011)—e.g., Stegoelmis sp and L. germari-were indicators of Cerrado and Atlantic Forest streams, showing a strict dependence of organic resources from surrounding vegetation to carry on their life history activities. Thus, they would hardly colonize streams outside their preferred biome and so all the explanation of their distribution would be due to environmental filtering, and not due to spatial distance.

The above-mentioned discussion is based on the premise that the studied organisms have the dispersal ability to arrive in streams of different biomes types. In this sense, aquatic beetles have a wide range of dispersal capacity, being, for example Hydrophilidae, 
Table 2 Results of species indicator analysis for saproxylic beetle taxa in streams of Cerrado and Atlantic Forest

\begin{tabular}{|c|c|c|c|c|c|}
\hline \multirow[t]{2}{*}{ Taxa } & \multirow[t]{2}{*}{ Abbreviation } & \multirow[t]{2}{*}{ Frequency $(\%)$} & \multicolumn{2}{|l|}{ Indicator value } & \multirow[t]{2}{*}{$p$ value } \\
\hline & & & Atlantic Forest & Cerrado & \\
\hline Lutrochus germari & Lut & 55 & 0.890 & 0.001 & 0.003 \\
\hline Heterelmis & Het & 77 & 0.581 & 0.205 & 0.209 \\
\hline Xenelmis & Xen & 50 & 0.187 & 0.312 & 0.696 \\
\hline Stegoelemis & Steg & 22 & 0.000 & 0.500 & 0.019 \\
\hline Microcylloepus & Mic & 5 & 0.100 & 0.000 & 1.000 \\
\hline Huleechius & Hul & 22 & 0.133 & 0.083 & 0.922 \\
\hline Phanocerus & Pha & 22 & 0.400 & 0.000 & 0.097 \\
\hline Macrelmis & Mac & 11 & 0.200 & 0.000 & 0.469 \\
\hline Promoresia & Pro & 5 & 0.100 & 0.000 & 1.000 \\
\hline Hexacylloepus & Hex & 33 & 0.037 & 0.406 & 0.209 \\
\hline Neoelmis & $\mathrm{Neo}$ & 33 & 0.084 & 0.197 & 0.792 \\
\hline Cylloepus & Cyl & 5 & 0.100 & 0.000 & 1.000 \\
\hline Elmidae spA & ElmA & 16 & 0.300 & 0.000 & 0.198 \\
\hline Elmidae spB & ElmB & 5 & 0.000 & 0.125 & 0.458 \\
\hline Elmidae spC & ElmC & 11 & 0.000 & 0.250 & 0.177 \\
\hline Austrolimnius & Aus & 5 & 0.100 & 0.000 & 1.000 \\
\hline Dryops & Dry & 50 & 0.472 & 0.081 & 0.217 \\
\hline Ptilodactilidae spA & Pti & 44 & 0.368 & 0.098 & 0.359 \\
\hline Hydraenidae spA & Hyd & 11 & 0.200 & 0.000 & 0.485 \\
\hline Staphylinidae spA & Sta & 33 & 0.600 & 00.000 & 0.011 \\
\hline Scirtidae spA & Sci & 33 & 0.282 & 0.073 & 0.435 \\
\hline Berosus & Ber & 11 & 0.200 & 00.000 & 0.482 \\
\hline Enochrus & Eno & 27 & 0.331 & 0.021 & 0.253 \\
\hline Derallus & Der & 16 & 0.300 & 0.000 & 0.213 \\
\hline Epimetopus & Epi & 5 & 0.100 & 0.000 & 1.000 \\
\hline Tropisternus & Tro & 5 & 0.100 & 0.000 & 1.000 \\
\hline Hydrochus & Hyd & 5 & 0.100 & 0.000 & 1.000 \\
\hline Gyretes & Gyr & 16 & 0.152 & 0.029 & 0.722 \\
\hline Genus H & Gen & 5 & 0.000 & 0.125 & 0.463 \\
\hline
\end{tabular}

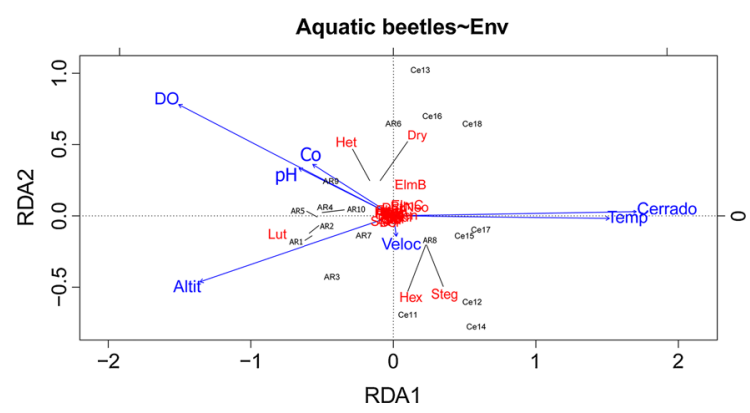

Fig. 4 Redundancy analysis using environmental variables as predictors for variation on community composition of aquatic beetles. DO dissolved oxygen, Altit altitude, Co conductivity, Veloc current velocity, Temp temperature. See Table 2 for taxa abbreviations
Dytiscidae and Gyrinidae known as good dispersers (Bilton et al. 2001). Although authors differ in opinions about riffle beetle dispersal, some genera were found in light traps in terrestrial systems, including Stegoelmis and Lutrochus (Brown 1987), and in general, the ability to fly varies among species and individuals of the same species (see reviews Brown 1987; Ellicott 2008). Indeed, after emergence (larvae pupate under debris or land alongside stream banks), adults could disperse away or entering in the water, but once the adults enter the water, they never leave it and cannot survive outside it (see review of Ellicott 2008). McCreadie and Bedwell (2014) also found that variation in elmid assemblages within a 
Table 3 Forward selection coupled with redundancy analysis for environmental matrix showing the fraction of variation explained by vegetation type (Cerrado) and dissolved oxygen concentration (DO) in taxonomic composition of aquatic beetles community

\begin{tabular}{llllllll}
\hline & & $\begin{array}{l}\text { Variables } \\
\text { order }\end{array}$ & $R^{2}$ & $R^{2}$ Cum & Adj $R^{2}$ & $F$ & $p$ value \\
\hline 1 & Cerrado & 7 & 0.251 & 0.251 & 0.204 & 5.363 & 0.001 \\
2 & DO & 2 & 0.0817 & 0.332 & 0.243 & 1.839 & 0.047 \\
\hline
\end{tabular}

Table 4 Relative importance of environmental and spatial variables selected in forward selection in explaining variation on taxonomic composition of aquatic beetles community

\begin{tabular}{|c|c|c|c|c|c|}
\hline & $D f$ & $R^{2}$ & $\operatorname{Adj} R^{2}$ & Testable & $p$ value \\
\hline Env + Shared & 2 & 0.332 & 0.243 & True & 0.025 \\
\hline Spa + Shared & 1 & 0.125 & 0.070 & True & 0.037 \\
\hline Env + Shared + Spa & 3 & 0.363 & 0.227 & True & 0.012 \\
\hline Individual fractions & & & & & Ns \\
\hline Pure Env & 2 & & 0.157 & True & 0.05 \\
\hline Shared Env + Sp & 0 & & 0.086 & False & Ns \\
\hline Pure Sp & 1 & & -0.016 & True & 0.1 \\
\hline Residual & & & 0.772 & False & Ns \\
\hline
\end{tabular}

Env environmental variables (Cerrado and dissolved oxygen), Spa spatial variables (spatial eigenvector 1). Shared refers to the spatial structuring in the species data that is shared by the environmental data. Ns not significant

stream basin scale was not explained by overland distance, indicating that they can probably disperse by overland routes. In this case, species could track environmental variation among streams in the extent of our study area, which is an integrated part of species sorting mechanism.

Cerrado and Atlantic Forest have distinct riparian composition (Oliveira-Filho and Ratter 2002) and also the plant species and individuals from these biomes have distinct woody structure (Marcati et al. 2001; Chave et al. 2006). As these small forested streams depend on allochthonous organic matter energy and aquatic beetles associated with woody debris use them, the composition and structure of riparian woody species should be important in providing specific habitats to this specialized fauna (McKie and Cranston 1998). This evidence is in line with the idea that woody species identity is an important factor affecting groups that use woody debris (McKie and Cranston 1998, 2001). In addition, the vegetation structure (forest canopy openness) together with geomorphological features of the channel could act in wood availability to aquatic beetles. In general, Cerrado streams are located in plain areas and have open and narrow riparian vegetation structure, which increase retention and facilitate wood falling by mechanical actions of winds (Liquori 2006; Cadol et al. 2009). On the other hand, high levels of declivity generally characterize Atlantic Forest, resulting in streams with poor retention of detritus. The continuous and dense structure of riparian vegetation constitutes a barrier for mechanical actions of winds, fundamental force for wood falling and input into streams (Cadol et al. 2009). This could produce less amount of woody debris available for aquatic beetles in Atlantic Forest streams compared with Cerrado streams. Although we did not measure wood availability during the fieldwork and recognized this caveat, the difference between Cerrado and Atlantic Forest streams was visually apparent. This difference in wood availability between Cerrado and Atlantic Forest streams is able to influence the assemblages of aquatic beetles since the availability of resources is a strong driver of the structure and dynamics of ecological systems (Nowlin et al. 2008).

Together with biome type, dissolved oxygen was an important environmental variable explaining the community composition of aquatic beetles corroborating the importance of local variables, such as physical and chemical characteristics of streams, for explaining 
aquatic insect community distribution (Siqueira et al. 2009; Roque et al. 2010). This variable was not correlated with other variables assessed here, including velocity, altitude and biome type, so it may affect community variation independently. Levels of dissolved oxygen such as those found in this study (ranging from 3 to $9 \mathrm{mg} / \mathrm{l}$ ) do not appear to be lethal to aquatic insects, but could be sufficient to lead variation in community composition (Connolly et al. 2004). Low levels of dissolved oxygen may affect growth through long-term, sub-lethal effects, such as suppressed emergence (Connolly et al. 2004). In addition, woody debris may create a microhabitat with lower levels of oxygen than water column (Spänhoff et al. 2000), intensifying these sub-lethal effects on specialist species.

The distinction between Cerrado and Atlantic Forest beetle assemblages was due to changes in both species identity and changes in species abundances. Most genera (19) occurred exclusively in one biome type but in low abundance and frequency, which do not characterize them as indicator species. The majority were generalist predators (e.g., Gyretes and Hydrophilidae genera), and their occurrence is sporadic in woody debris (Hoffmann and Hering 2000; Valente-Neto et al. 2015; Roque et al. 2015). In such cases, community patterns are mainly driven by abundant taxa, such as specialists and few generalists elmids. Although generalist elmids (e.g., Heterelmis, Hexacylloepus and Neolmis) were found in both biome types, their abundance differs between biomes. This difference could be related to differences in declivity among Cerrado and Atlantic Forest streams, since Atlantic Forest streams has greater variation in declivity and would have more habitats for riffle beetles. Specialists also contributed for the assemblage variation between biomes, such as the specificity showed by Stegoelmis for Cerrado streams, as also found by Segura et al. (2011) and Lutrochus for Atlantic Forest stream. Some elmids are poorly known regarding their affinity and dependence of woody debris as habitat and feeding source (Segura et al. 2012), but our observations during sample processing suggested that Elmidae spB and spC (found exclusively in Cerrado streams) are borers and gougers of woody debris. Altogether, these results are in line with studies showing the importance of organic substrates (specific to each biome) and that colonizers of woody debris are a set of opportunistic to specialist species
(Steedman and Anderson 1985; McKie and Cranston 1998; Valente-Neto et al. 2015).

Streams are highly variable systems, both hydrographic and environmentally. These characteristics would be responsible for a high temporal variation of community composition and could affect explanation power of environmental variables. In this sense, although snapshot studies do not include this variation in community composition as well as in environmental variables, they are suitable to capture overall trends in community composition, mainly the most abundant organisms. We detected that dissolved oxygen and biome type explained about $25 \%$ of community variation, an amount of explanation that is similar to other snapshot metacommunity studies (see review Soininen 2014). Moreover, our study did not include more samples on the transition region. Both Cerrado and Atlantic Forest biomes are highly fragmented in the transition region, turning streams under low human impact hard to find. Including more samples from the transition region could not change our result of environment filtering but would likely reinforce it, because the most abundant taxa appear to be biome specific, i.e., Lutrochus and Stegoelmis in Atlantic Forest and Cerrado streams, respectively.

In conclusion, we found evidence for a role of biome type and dissolved oxygen explaining the structure of saproxylic beetles in streams. The relationship of wood debris and the surrounding vegetation explained the distinct community of insects associated with this substrate among Cerrado and Atlantic Forest streams. Specialized taxa, such as Stegoelmis and L. germari were, respectively, restricted and abundant in only one biome, while generalist species were common in both biomes. The relationship among saproxylic beetles and their substrate, together with the lack of evidence of dispersal-related processes, corroborate an explanation of species sorting driving variation in community structure of saproxylic beetles, both via changes in species identity and in species relative abundance.

Acknowledgments We are grateful to Daniel G. da Fonseca, Fabio T. T. Hanashiro, Melissa O. Segura, Ricardo Koroiva, and Rogério Libório for helping to collect and process the submerged woody debris, to Jose Manuel Ochoa Quintero, Fabio O. Roque, Ricardo Koroiva, Suzana Escarpinati, Fábio T. T. Hanashiro and Mariya Shcheglovitova for their valuable comments that improved this manuscript, to the Environment Secretary and Forest Institute of São Paulo State for authorizing the collection of material (process number 260108-017.776/2009) at Campos do Jordão State Park and Atlantic Forest State Park (Santa 
Virginia Unit) and to the staff of these conservation units for the logistic support. This study was partially funded by Grant \#131605/2010-0, Conselho Nacional de Desenvolvimento Científico e Tecnológico $(\mathrm{CNPq})$. The writing of this study was partially funded by Grants \#2013/50424-1 and \#2013/ 20540-0, São Paulo Research Foundation (FAPESP), by Grant \#480933/2012-0, CNPq and by Grant \#23/200.578/2012, Fundação de Apoio ao Desenvolvimento do Ensino, Ciência e Tecnologia do Estado de Mato Grosso do Sul (FUNDECT).

\section{References}

Anderson MJ (2001) A new method for non-parametric multivariate analysis of variance. Aust Ecol 26:32-46

Anderson MJ, Ellingsen KE, McArdle BH (2006) Multivariate dispersion as a measure of beta diversity. Ecol Lett 9:683-693

Bilton DT, Freeland JR, Okamura B (2001) Dispersal in freshwater invertebrates. Annu Rev Ecol Syst 32:159-181

Blanchet FG, Legendre P, Borcard D (2008) Forward selection of explanatory variables. Ecology 89:2623-2632

Borcard D, Legendre P (2002) All-scale spatial analysis of ecological data by means of principal coordinates of neighbour matrices. Ecol Model 153:51-68

Borcard D, Legendre P, Drapeau P (1992) Partialling out the spatial component of ecological variation. Ecology 73 : $1045-1055$

Brown HP (1987) Biology of riffle beetles. Ann Rev Entomol 32:253-273

Cadol D, Wohl E, Goode JR, Jaeger KL (2009) Wood distribution in neotropical forested headwater streams of La Selva, Costa Rica. Earth Surf Proc Land 34:1198-1215

Chave J, Muller-Landau HC, Baker TR, Easdale TA, Steege HT, Webb CO (2006) Regional and phylogenetic variation of wood density across 2456 neotropical tree species. Ecol Appl 16:2356-2367

Connolly NM, Crossland MR, Pearson RG (2004) Effect of low dissolved oxygen on survival, emergence, and drift of tropical stream macroinvertebrates. J N Am Benthol Soc 23:251-270

Corkum LD (1992) Spatial distributional patterns of macroinvertebrates along rivers within and among biomes. Hydrobiologia 239:101-114

Cranston P, McKie B (2006) Aquatic wood-an insect perspective. In: Grove SJ, Hanula JL (eds) Insect biodiversity and dead wood: proceedings of a symposium for the $22 \mathrm{nd}$ international congress of entomology. US Department of Agriculture Forest Service, Asheville, pp 9-14

Domínguez E, Fernández HR (2009) Macroinvertebrados bentónicos sudamericanos: sistemática y biologia. Fundación Miguel Lillo, Tucumán

Dray S, Legendre P, Peres-Neto PR (2006) Spatial modelling: a comprehensive framework for principal coordinate analysis of neighbour matrices (PCNM). Ecol Model 196:483-493

Dray S, Legendre P, Blanchet G (2011) packfor: forward selection with permutation. R package version $0.0-8 / \mathrm{r} 100$

Dufrêne M, Legendre P (1997) Species assemblages and indicator species: the need for a flexible asymmetrical approach. Ecol Monogr 67:345-366
Durigan G (2006) Observations on the Southern Cerrados and their relationship with the core area. In: Pennington RT, Lewis GP, Ratter JA (eds) Neotropical savannas and seasonally dry forests: plant diversity, biogeography, and conservation. CRC Press, New York, pp 67-77

Ellicott JM (2008) The ecology of riffle beetles (Coleoptera: Elmidae). Freshw Rev 1:189-203

Feminella JW (2000) Correspondence between stream macroinvertebrate assemblage and 4 ecoregions of the southeastern USA. J N Am Benthol Soc 19:442-461

Fundação SOS Mata Atlântica (2013) Atlas dos remanescentes florestais da mata atlântica período 2011-2012. São Paulo. https://www.sosma.org.br/wp-content/uploads/2013/06/ atlas_2011-2012_relatorio_tecnico_2013final.pdf

Gosz JR, Sharpe PJH (1989) Broad-scale concepts for interactions of climate, topography, and biota at biome transitions. Landsc Ecol 3:229-243

Griffith DA, Peres-Neto P (2006) Spatial modeling in ecology: the flexibility of eigenfunction spatial analyses. Ecology $87: 2603-2613$

Hoffmann A, Hering D (2000) Wood-associated macroinvertebrate fauna in Central European streams. Int Rev Hydrobiol 85:25-48

Kaller MD, Kelso WE (2007) Association of macroinvertebrate assemblages with dissolved oxygen concentration and wood surface area in a selected subtropical streams of the southeastern USA. Aquat Ecol 41:95-110

Kronka FJN, Nalon MA, Matsukuma CK, Kanashiro MM, Ywane MSS, Pavão M, Durigan G, Lima LMPR, Guillaumon JR, Baitello JB, Borgo SC, Manetti LA, Barradas AMF, Fukuda JC, Shida CN, Monteiro CHB, Pontinha AAS, Andrade GG, Barbosa O, Soares AP (2005) Inventário florestal da vegetação natural do estado de São Paulo. Secretaria do Meio Ambiente; Instituto Florestal; Imprensa Oficial, São Paulo, p 200p

Legendre P, Gallagher ED (2001) Ecologically meaningful transformations for ordination of species data. Oecologia 129:271-280

Legendre P, Legendre L (2012) Numerical ecology. Elsevier, Amsterdam

Leibold MA, Holyoak M, Mouquet N, Amarasekare P, Chase JM, Hoopes MFF, Holt RD, Shurin JB, Law R, Tilman D, Loreau M, Gonzalez A (2004) The metacommunity concept: a framework for multi-scale community ecology. Ecol Lett 7:601-613

Liquori MK (2006) Post-harvest riparian buffer response: implications for wood recruitment modelling and buffer design. J Am Water Resour As 4184:177-189

Logue JB, Mouquet N, Peter H, Hillebrand H, Declerck P, Flohre A, Gantner S, Gulzow N, Hörtnagl P, Meier S, Pecceu B (2011) Empirical approaches to metacommunities: a review and comparison with theory. Trends Ecol Evol 26:482-491

Lomolino MV, Riddle BR, Whittaker R, Brown JH (2010) Biogeography. Sinauer Associates, Sunderland

Lorenzi H (2002) Árvores brasileiras: manual de identificação e cultivo de plantas arbóreas nativas do Brasil. Intituto Plantarum, Nova Odessa

Marcati CR, Angyalossy-Alfonso V, Benetati L (2001) Comparative wood anatomy of Copaifera langsdorffii Desf. 
(Leguminosae-Caesalpinoideae) in forest and "cerradão".

Rev Bras Bot 24:311-320

McCreadie JW, Bedwell C (2014) Species composition of local riffle beetle (Coleoptera: Elmidae) assemblages in small coastal streams of the Gulf of Mexico: the influences of local and regional factors. Aquat Ecol 48:127-141

Mckie B, Cranston PS (1998) Keystone coleopterans? Colonisation by wood-feeding elmids of experimentally-immersed woods in south-east Australia. Mar Freshw Res 49:79-88

Mckie B, Cranston PS (2001) Colonisation of experimentally immersed wood in south eastern Australia: responses of feeding groups to changes in riparian vegetation. Hydrobiologia 452:1-14

McKnight MW, White PS, McDonald RI, Lamoreux JF, Sechrest W, Ridgely RS, Stuart SN (2007) Putting betadiversity on the map: broad-scale congruence and coincidence in the extremes. PLoS Biol 5:e272. doi:10.1371/ journal.pbio. 0050272

Morellato LPC, Haddad CFB (2000) Introduction: the Brazilian Atlantic Forest. Biotropica 32:786-792

Mouquet N, Loreau M (2003) Community patterns in sourcesink metacommunities. Am Nat 162:544-557

Mykrä H, Heino J, Muotka T (2004) Variability of lotic macroinvertebrate assemblages and stream habitat characteristics across hierarchical landscape classifications. Environ Manag 34:341-352

Nekola JC, White PS (1999) The distance decay of similarity in biogeography and ecology. J Biogeogr 26:867-878

Nowlin WH, Vanni MJ, Yang LH (2008) Comparing resource pulses in aquatic and terrestrial ecosystems. Ecology 89:647-659. doi:10.1890/07-0303.1

Oksanen J, Blanchet FG, Kindt R, Legendre P, Minchin PR, O’Hara RB, Simpson GL, Solymos P, Henry M, Stevens H, Wagner H (2014) Vegan: community ecology package. R package version 2.2-0. http://CRAN.R-project.org/ package=vegan

Oliveira PS, Marquis RJ (2002) The cerrados of Brazil: ecology and natural history of a neotropical Savana. Columbia University Press, New York

Oliveira-Filho AT, Ratter JA (2002) Vegetation physiognomies and woody flora of the Cerrado Biome. In: Oliveira PS, Marquis RJ (eds) The Cerrados of Brazil: ecology and natural history of a Neotropical savannah. Columbia University Press, New York, pp 91-120

Peres-Neto PR, Legendre P, Dray S, Borcard D (2006) Variation partitioning of species data matrices: estimation and comparison of fractions. Ecology 87:2614-2625

Poff NL (1997) Landscape filters and species traits: towards mechanistic understanding and prediction in stream ecology. J N Am Benthol Soc 16:391-409

Ratter JA, Dargie TCD (1992) An analysis of the floristic composition of 26 cerrado areas in Brazil. Edinb J Bot 49:235-250

Roque FO, Lecci LS, Siqueira T, Froehlich CG (2008) Using environmental and spatial filters to explain stonefly occurrences in southeastern Brazilian streams: implications for biomonitoring. Acta Limnol Bras 20:35-44

Roque FO, Siqueira T, Bini LM, Ribeiro MC, Tambosi LR, Ciocheti G, Trivinho-Strixino S (2010) Untangling associations between chironomid taxa in Neotropical streams using local and landscape filters. Freshw Biol 55:847-865

Roque FO, Escarpinati SC, Valente-Neto F, Hamada N (2015) Responses of aquatic saproxylic macroinvertebrates to reduced-impact logging in central Amazonia. Neotrop Entomol 44:345-350

Sanchez M, Pedroni F, Leitão-Filho HF, Cesar O (1999) Composição florística de um trecho de floresta ripária na Mata Atlântica em Picinguaba, Ubatuba, SP. Rev Bras Bot 22:31-42

Scudeller VV, Martins FR, Shepard GJ (2001) Distribution and abundance of arboreal species in the atlantic ombrophilous dense forest in Southeastern Brazil. Plant Ecol 152:185-199

Segura MO, Valente-Neto F, Fonseca-Gessner AA (2011) Elmidae (Coleoptera, Byrrhoidea) larvae in the state of São Paulo, Brazil: identification key, new records and distribution. ZooKeys 151:53-74. doi:10.3897/zookeys.151. 1879

Segura MO, Fonseca-Gessner AA, Spies MR, Siegloch AE (2012) Water beetles in mountainous regions in southeastern Brazil. Braz J Biol 72:311-321

Siqueira T, Bini LM, Cianciaruso MV, Roque FO, TrivinhoStrixino S (2009) The role of niche measures in explaining the abundance-distribution relationship in tropical lotic chironomids. Hydrobiologia 636:163-172

Soares JJ, Silva DW, Lima MIS (2003) Current state and projection of the probable original vegetation of the São Carlos region of São Paulo state, Brazil. Braz J Biol 63:527-536

Soininen J (2014) A quantitative analysis of species sorting across organisms and ecosystems. Ecology 95:3284-3292

Sokal RR, Oden NL (1978) Spatial autocorrelation in biology. 1. Methodology. Biol J Linn Soc 10:199-228

Spänhoff B, Alecke C, Meyer EI (2000) Colonization of submerged twigs and branches of different wood genera by aquatic macroinvertebrates. Int Rev Hydrobiol 85:49-66

Steedman RJ, Anderson NH (1985) Life history and ecological role of the xylophagous aquatic beetle, Lara avara LeConte (Dryopoidea: Elmidae). Freshw Biol 15:535-546

Valente-Neto F, Fonseca-Gessner AA (2011) Larvae of Lutrochus germari (Lutrochidae: Coleoptera) and Stegoelmis sp. (Elmidae: Coleoptera) bore submerged woody debris in Neotropical streams. Zoologia (Curitiba) 28:683-696

Valente-Neto F, Koroiva R, Fonseca-Gessner AA, Roque FO (2015) The effect of riparian deforestation on macroinvertebrates associated with submerged woody debris. Aquat Ecol 49:115-125. doi:10.1007/s10452-015-9510-y

van Rensburg BJ, Levin N, Kark S (2009) Spatial congruence between ecotones and range-restricted species: implications for conservation biogeography at the sub-continental scale. Divers Distrib 15:379-389 